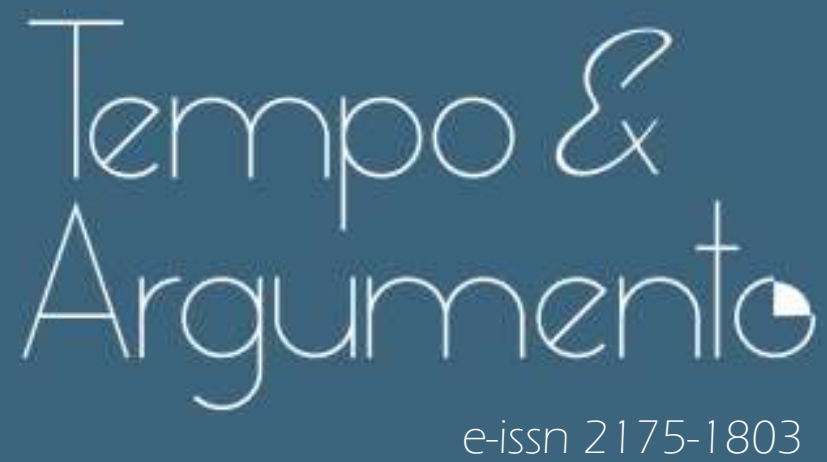

Maternidad, justicia y robo de niños y niñas: demandas de mujeres que buscan a sus hijas e hijos robados en Argentina

Soledad Gesteira

Doctora en Antropología Social por la Universidad de Buenos Aires (UBA).

Investigadora del Consejo Nacional de Investigaciones en Ciencia y Técnica (CONICET).

Buenos Aires - ARGENTINA

uba.academia.edu/SoledadGesteira

soledadgesteira@gmail.com

(10) orcid.org/0000-0003-1253-5902

Para citar este articulo (ABNT):

GESTEIRA, Soledad. Maternidad, justicia y robo de niños y niñas: demandas de mujeres que buscan a sus hijas e hijos robados en Argentina. Tempo e

Argumento, Florianópolis, v. 13, n. 33, e0205, maio/ago. 2021.

do http://dx.doi.org/10.5965/2175180313332021 e0205

Recebido: 09/07/2020

Aprovado: 15/03/2021 


\title{
Maternidad, justicia y robo de niños y niñas: demandas de mujeres que buscan a sus hijas e hijos robados en Argentina
}

\begin{abstract}
Resumen
En Argentina, a partir del 2000, inspirados por la lucha de Abuelas de Plaza de Mayo, comienzan a surgir organizaciones de personas que buscan sus orígenes. Desde sus inicios estas organizaciones recibieron a mujeres que buscaban a sus hijos/as robados/as, manifestando que fueron dados por muertos, que "nunca les mostraron el cuerpo" ni les dieron certificado de defunción. Rosa, es una de esas mujeres, nació en 1954 y a los catorce años tuvo un hijo/a en un consultorio clandestino de una partera en la provincia de Buenos Aires. Denuncia que ella se "lo robo" y fue una testigo clave en el juicio en donde tres mujeres lograron condenar a esa partera a doce años de prisión por haberlas vendido al nacer. Este artículo, tomando las entrevistas en profundidad a Rosa y a otras mujeres en su situación y los registros etnográficos del juicio a la partera, apunta a comprender, por un lado, los sentidos de justicia, maternidad y abandono presentes en los relatos de estas mujeres, y por otro, la configuración de estas demandas por robo de niños en el terreno judicial. De este modo, a partir de conocer los discursos que se construían entorno a estas mujeres y sus embarazos que, en su mayoría, atentaban contra las formas legítimas de concebir la familia y el parentesco, intento dar cuenta de la experiencia histórica de estas mujeres a luz de la intersección entre clase, género y edad y de los modos en que estas experiencias son resignificadas en la actualidad.
\end{abstract}

Palabras clave: Maternidad; Robo de niños y niñas; Mujeres; Justicia; Argentina.

\section{Maternity, justice and stealing of children: demands of women looking for their stolen children in Argentina}

\begin{abstract}
Since the year 2000, inspired by the struggle of the organization "Abuelas de Plaza de Mayo", other organizations of people seeking their origins begin to emerge in Argentina. Form the beginning these organizations received women who were looking for their stolen children, stating that they were presumed dead, that nobody "never showed them the body" or that they never received a death certificate. One or those women is Rosa, who was born in 1954 and at the age of fourteen had a son in a midwife's clandestine clinic in the province of Buenos Aires. Rosa claims that she "stole it" and was a key witness in the trial where three women managed to sentence that midwife to twelve years in prison for having sold them at birth. In this article, trough in-deph interviews with Rosa and other women in the same situation, and ethnographic records of the midwife trial, I aim to understand, on the hand, the senses of justice, motherhood and abandonment present in these women's, and on the other, the configuration of these stolen children demands in the field of justice. In this way, through the discourses built around these women and their pregnancies which, in their majority, threatened the legitimate ways of conceiving family and kinship, I try give account of the historical experience of these women intersected by class, gender and age and the ways in which these experiences are currently resignified.
\end{abstract}

Keywords: Maternity; Stolen children; Women; Justice; Argentina. 
Búsqueda de los orígenes y acceso a la justicia en Argentina ${ }^{1}$

En Argentina, a partir del 2000, inspirados por la lucha de Abuelas de Plaza de Mayo en la búsqueda de sus nietos/as apropiados criminalmente durante la última dictadura militar (1976-1983)2, comienzan a surgir organizaciones de personas que quieren conocer sus orígenes y reclaman por su derecho a la identidad. Algunos fueron adoptados, pero en su mayoría fueron anotados en el registro civil como hijos/as biológicos/as de quienes los criaron, es decir que hubo una falsa inscripción de la filiación, una acción que al tiempo que es un delito estipulado en el código penal, supone la sustitución de la identidad de ese niño o niña ${ }^{3}$. Estas personas, interpeladas por la labor de Abuelas de Plaza de Mayo, comenzaron a preguntarse por su identidad y sus orígenes y al no existir organismos de Estado dedicados a su problemática deciden crearlos ${ }^{4}$. Así surge en 2002 la primer ONG dedicada a la problemática de la búsqueda de los orígenes, Quienes Somos, en 2003 Raíz Natal, en 2010 Búsquedas Verdades Infinitas y una enorme cantidad de grupos virtuales y comunidades de Facebook que crece día a día.

\footnotetext{
Este texto se basa en una ponencia presentada en las Jornadas de la Sección de Antropología Social de 2018 (Buenos Aires, Argentina). Fue reelaborado en el marco del Programa de Posdoctorado en Ciencias Humanas y Sociales de la Facultad de Filosofía y Letras de la Universidad de Buenos Aires (FFyL-UBA) y a partir de las contribuciones que me brindó la estancia posdoctoral realizada durante 2019 en el equipo Historia de las Familias y las Infancias en la Argentina contemporánea (dirigido por Isabella Cosse) del Instituto Interdisciplinario de Género (FFyL-UBA). Le agradezco a sus integrantes por la lectura y los enriquecedores comentarios a este texto y muy especialmente a Isabella Cosse, directora de mi Posdoctorado, por la posibilidad de recibirme en su equipo e integrarme con tanta amabilidad, compromiso y afecto, por sus atentas lecturas y sus generosas ideas.

2 Si bien la denuncia y problematización de estos hechos lograron convertirlos en crímenes que fueron más allá de los límites de lo pensable (VILLALTA, 2012) cabe señalar que la práctica de apropiación de niños y el borramiento de su identidad en Argentina se remonta a las campañas militares realizadas en el marco del genocidio indígena (DELRÍO; RAMOS, 2011).

${ }^{3}$ Isabella Cosse (2007) analizando casos de personas nacidas como hijos ilegítimos en los años 40 en Argentina conceptualiza a la filiación ilegítima a través de la noción de vulnerabilidad, entendida como un cuadro de minusvalías de derecho, sociales y simbólicas que estaban definidas en el momento del nacimiento (COSSE, 2007). La noción de vulnerabilidad resulta interesante conectarla con las expresiones actuales de personas que buscan sus orígenes quienes argumentan que sienten un "vacío" o se sienten "incompletos" por no conocer una parte de su historia, incluso explícitamente sostienen que ha sido "vulnerado" su derecho a la identidad (GESTEIRA, 2016).

${ }^{4}$ Esta interpelación también se relaciona con las formas en que en occidente es conceptualizado y vivenciado el parentesco y la familia donde el peso de la biología tiene un rol central (SCHNEIDER, 1984), así el conocimiento sobre los orígenes biológicos se vuelve una información relevante y determinante para la construcción de la identidad de los individuos.
} 
Durante mi investigación antropológica con estos activistas (GESTEIRA, 2016) pude saber que desde sus inicios y en forma creciente, estas asociaciones comenzaron a recibir a madres que buscaban a sus hijos/as robados/as o entregados al nacer, solicitando ayuda para poder buscarlos. En los últimos años se puede observar en las redes sociales (de grupos de búsqueda de personas o web de asociaciones) la presencia, en aumento, de los testimonios de estas mujeres que hoy tienen entre 50 y 70 años, y que -lentamente-comienzan a contar sus historias, difundir sus búsquedas y organizarse ${ }^{5}$. Ellas argumentan que sus niños fueron dados por muertos y que "nunca les mostraron el cuerpo" ni les dieron certificados de defunción, que fueron obligadas a entregarlos o que lo hicieron de forma voluntaria, pero luego se arrepintieron ${ }^{6}$. Muchas de estas mujeres eran adolescentes en esos momentos, provenían de sectores populares, o bien sus embarazos eran "vergonzosos" y debían ocultarlos?. Ello así porque en su mayoría eran embarazos por fuera del matrimonio legal, que ponían en cuestión el honor y respetabilidad de las familias "bien constituidas". Esto es, esas maternidades se encontraban por fuera de las formas legítimas de construir-y concebir- la familia y el parentesco.

Una de estas mujeres es Rosa ${ }^{8}$ que nació en 1954, actualmente tiene sesenta y seis años, y cuando tenía catorce tuvo un hijo/a en uno de los consultorios clandestinos de una partera de González Catán y denuncia que ella se "lo robo". Esa misma partera fue condenada en 2012 a doce años de prisión en un juicio que marcó un antes y un después en la comprensión y conceptualización de derecho a la identidad en Argentina, pues es la primera vez que se condena a una "partera vende niños" por fuera de los casos de lesa humanidad (GESTEIRA, 2016). Este juicio fue motorizado por tres mujeres que

\footnotetext{
5 Tal es el caso de la organización Madres en Búsqueda y Madres por la Verdad, ambas creadas en 2017. Y el Colectivo Mendoza por la Verdad, que reúne tanto a madres que les robaron a sus hijos, como a personas que buscan sus orígenes y surge en 2015 por la iniciativa de una mujer a la que le robaron su hija en esa provincia en 1984 cuando tenía 17 años.

- Si algunas de las ideas vertidas en este artículo y sobre los casos de estas mujeres pueden evocar al análisis en torno a la "maternidad subrogada" o al "alquiler de vientres", cabe precisar que no es objetivo de este texto debatir y/o reflexionar sobre estos casos en esa clave de lectura.

Historias similares son recogidas por Karen Alfaro Monsalve (2019) en Chile con testimonios mujeres que fueron víctimas de prácticas de sustracción y adopciones forzadas de niñas/os pobres durante la dictadura militar en ese país, insertas en políticas de regulación de la población y como parte de mecanismos de violencia social contra mujeres pobres.

${ }^{8}$ Los nombres reales de las personas entrevistadas durante el trabajo de campo han sido modificados.
} 
fueron vendidas por la partera, entre ellas Luz, una potente activista que mantiene un fuerte lazo con Rosa.

En mi investigación, sobre la base del trabajo de campo etnográfico realizado desde 2010 y entrevistas en profundidad a las tres mujeres que fueron vendidas al nacer y que denunciaron a la partera y a sus abogados, analicé las experiencias de estas mujeres llevando sus demandas por conocer sus orígenes al terreno judicial. Un espacio y una forma de activismo (MERRY, 2010; TISCORNIA, 2008) que cuando comencé a investigar sobre estos temas parecía "imposible", tal como lo expresaban los integrantes de la Asociación Raíz Natal9. Por un lado, porque los delitos a los que refieren las inscripciones falsas de la filiación de estas personas prescriben ${ }^{10}$ (exceptuando los casos de los niños apropiados durante la dictadura militar, que se consideran delitos de lesa humanidad), y por otro lado, porque al no ser adopciones legales, no cuentan con registros que tengan información sobre sus progenitores ${ }^{11}$.

En la causa de la partera, Rosa fue una testigo clave en el juicio, pues su testimonio dio cuenta de la trama de robo y venta de niños que tenía lugar en los consultorios clandestinos de la partera. Actualmente, Rosa y otras cinco personas vendidas por la partera le iniciaron una segunda causa judicial, sin embargo, ninguno de ellos ha logrado conocer sus orígenes.

En este artículo, a partir de entrevistas en profundidad a mujeres que les robaron a sus hijos/as ${ }^{12}$ y del trabajo de campo etnográfico con activistas y durante el juicio a la partera, describo y analizo los casos de Rosa y también de Amanda otra mujer que busca a su hijo robado y que inició una causa judicial. A

\footnotetext{
${ }^{9}$ Organización donde comencé mi trabajo de campo en 2010.

${ }^{10}$ Los delitos tipificados por el Código Penal para el robo de niños son: sustracción, retención y ocultamiento de un niño menor de 10 años (artículo 146, con penas de 5 a 15 años), suposición y sustitución de estado civil (artículos 138 y 139, con penas de 1 a 6 años), y falsedad ideológica de instrumentos públicos (artículo 293, con penas de 1 a 6 años), en su conjunto son delitos que prescriben luego de 12 años.

${ }^{11}$ En la inscripción falsa no existen huellas burocráticas donde queda registrada la información relativa a la madre biológica de la persona, de modo que estas búsquedas de origen resultan muy complejas. Por su parte, en la adopción hay un expediente que contiene dicha información y el nuevo Código Civil establece que se puede acceder sin límite de edad.

12 Durante el transcurso de mi beca posdoctoral CONICET (2017-2019) realicé entrevistas en profundidad a diez madres que buscan a sus hijos y realicé trabajo de campo en las actividades de las agrupaciones Madres en Búsqueda y Madres por la Verdad, asimismo he mantenido entrevistas informales con el resto de las madres que forman de estas agrupaciones y con madres "independientes" es decir que no integran ninguna agrupación.
} 
partir de este análisis me propongo comprender, por un lado, los sentidos de justicia, maternidad y abandono presentes en los relatos de estas mujeres, y por otro, como se configuran estas demandas por robo y apropiación de niños en el terreno judicial.

A continuación, presento una breve descripción biográfica de Rosa y Amanda que son los casos que serán analizados en el artículo. En los dos apartados siguientes examino, retomando aportes de la historia y la antropología, por un lado, los sentidos sobre maternidad, justicia y abandono presentes en este tipo de casos y los mandatos sociales y disciplinamientos morales que han experimentado estas mujeres y como se configuran sus demandas por el robo de sus hijos/as en el terreno judicial. Y por otro lado, el lazo que une estos casos con cuestiones y debates de actualidad colocados en la agenda pública por el feminismo (aborto, ley de educación sexual integral). Por último, elaboro algunas reflexiones sobre las prácticas de circulación coactiva de niños/as en Argentina y las características de la experiencia histórica de las mujeres atendiendo a la intersección entre las categorías género, clase y edad.

\section{Rosa y Amanda: mujeres que buscan a sus hijas e hijos robados}

Antes presentar algunas de las historias que conocí sobre mujeres que buscan a sus hijos/as robados/as, quisiera adelantar que se trata de relatos que tienen un marcado componente emocional, al igual que mi inmersión en esta investigación y de quienes conocen de cerca los casos de estas mujeres. Si bien no es un tema que analizaré en este texto, resulta central tener presente el valor que adquieren los sentimientos y emociones en el activismo y en la construcción y legitimación de las demandas de justicia ${ }^{13}$.

Rosa es una mujer de pequeña estatura, ojos marrones, cabello castaño y una voz placida y dulce. Habla pausadamente y con ese tono transcurre nuestra entrevista en su casa de González Catán, provincia de Buenos Aires. Durante nuestro encuentro se emociona en muchas ocasiones, al igual que las veces que

\footnotetext{
13 Sobre este punto he realizado una reflexión en el artículo "'Nosotros lo sentimos'. Emociones y saberes em las búsquedas de origen biológico de personas adoptadas o inscriptas falsamente em Argentina". RBSE - Revista Brasileira de Sociologia da Emoção, v. 11, n. 32, pp. 314-344, 2012.
} 
la vi durante mi trabajo de campo en el primer juicio a la partera y también en su entrevista para el documental Mujeres Invisibles (2017) ${ }^{14}$. Su vida fue muy difícil, además del robo de su hijo/a, falleció una hija de ocho meses de meningitis en 1978 y tuvo una difícil infancia debido, en parte, a que sus padres eran muy pobres. Nació en 1954 en el paraje de Monte Quemado en la provincia del Chaco ${ }^{15}$, y transcurrió su infancia con sus ocho hermanos en el pueblo chaqueño Pampa del Infierno. Rosa recuerda que en el Chaco "la vida era dura" (ROSA, 2018, entrevista oral) ${ }^{16}$ y que no iban a la escuela porque tenían que cosechar algodón “meses y meses". Siendo una niña su padre, que era hachero en un obraje, se enferma y un tío decide llevarlo a Buenos Aires y designan a Rosa para que viaje para solventar los gastos de su padre. Rosa recuerda: "me mandaron a mí, que era una nena, tenía doce años, sin conocer nada. Siempre me pregunto por qué me mandaron a mí, mi hermano más grande tenía dieciocho años" (ROSA, 2018, entrevista oral). Trabajaba limpiando en una casa de familia y los fines de semana le lavaba la ropa a su padre. Así narra el impacto que supuso venir a Buenos Aires:

"Lo más triste era que salí del campo de cosechar algodón a limpiar una casa y la señora me retaba todo el tiempo: "como será tu madre que no te enseño a limpiar, no sabes limpiar un piso". Allá [en Chaco] nunca había visto un piso, todo era tierra, eran ranchos donde vivíamos (se emociona y llora). Bueno, me llevaba muchos retos de la señora, mi tía nunca le explicaba que recién me habían traído del campo, yo le quería explicar, pero no me entendían, o no sabrían que la gente pobre viene de un lugar que no tenés cerámica, no tenés azulejos. Hasta que caí en una familia turca con seis chicos y me tomaron como niñera de la última nena y ahí me quedé embarazada de mi bebé. Ellos eran buenos, me querían y yo los quería a ellos". (ROSA, 2018, entrevista oral)

La historia de Amanda, otra mujer que busca a su hijo robado, encuentra muchas similitudes con la de Rosa. Amanda tiene 64 años es una mujer alegre,

\footnotetext{
${ }^{14}$ Dirigido por Clara Becerra y realizado desde la Dirección de registro de Personas Desaparecidas de la Provincia de Buenos coordinada por Alejandro Inchaurregui. El documental narra la historia de seis mujeres de diferentes edades y clases sociales que fueron madres y que por diversas razones se separaron de algún hijo. Está disponible en: https://www.youtube.com/watch?v=FuzqlNaCAT4.

15 Provincia argentina ubicada al noreste del país, su capital es la ciudad de Resistencia, su economía se ha basado históricamente en algodón, producción de ganado vacuno, extracción de madera y más recientemente cultivo de soja. En el censo de 1947 contaba con 430.555 habitantes y en 1960 con 543.331 habitantes.

16 Los extractos encomillados del artículo corresponden a citas textuales de entrevistas orales realizadas por la autora.
} 
activa y muy amable. La conocí en 2014 a través de los integrantes de asociación Raíz Natal durante mi trabajo de campo, allí todos hablaban de Amanda: "ella es una mamá que busca, que le robaron a su hijo y que hace años lo está buscando, hizo de todo", "para nosotros es un ejemplo", "nosotros la cuidamos mucho y la acompañamos", comentarios del estilo eran proferidos por los integrantes de la Raíz Natal. Amanda me recibió en su casa de Tigre una mañana fría y soleada del 19 de junio de 2014. Ella nació en Gualeguay, Entre Ríos y tuvo nueve hermanos. "Gente de campo, italianos, gente muy fría, cuando sos chica no ves" (AMANDA, 2014, entrevista oral). Su padre era alcohólico y a los nueve años la llevaron a trabajar en una casa de familia, ella recuerda: "la pasé muy mal, te hacían fregar un piso, un techo, una ventana, cualquier cosa... así fui creciendo de casa en casa y lo que ganaba tenía darselo a mis padres, igual que mis hermanos".

Amanda no pudo asistir a la escuela. En esa mañana soleada pero fresca Amanda me cuenta lo difícil que fue su infancia, las diferentes casas donde estuvo, cómo le pegaban o la encerraban con llave siendo una niña, incluso los fines de semana cuando iba a casa de sus padres en el campo tenía que juntar zapallos, sembrar papa, barrer, limpiar, bañar a sus. Entre esos maltratos que recibió también hará referencia a abusos sexuales de sus "patrones". Ella me dirá: “ese tipo me manoseo toda, pero a sillazos lo agarré y me escapé por la ventana". Cuando tenía diecisiete años Amanda se enamoró de un amigo de su hermano y quedó embarazada, así lo recuerda: “yo no sabía ni cuanto era dos más dos, me voy a cama con él, yo qué sabía lo que me iba pasar, viste la ignorancia, ay, por no saber nada, nada de la vida, por Dios!” (AMANDA, 2014, entrevista oral).

\section{Maternidad y mandatos sociales: entre embarazos, partos y robos}

Las historias de mujeres como Rosa y Amanda junto al resto de los casos que relevé en mi investigación posdoctoral conducen a preguntarnos quiénes eran estas mujeres, qué discursos se construían entorno a ellas y sus embarazos y cómo en la actualidad deciden reclamar por el robo de sus hijos/as en el terreno judicial. Para poder acercar algunas reflexiones entorno a estos interrogantes es preciso conocer como fueron vivenciados los embarazos por estas mujeres. 
Mientras Rosa trabaja en Buenos Aires en una casa de familia queda embarazada, pero al comienzo no sabía que ese aumento de peso se debía a su estado, recién a los cinco meses "se dio cuenta”. Su padre ya había regresado al Chaco y habían venido dos de sus hermanos. Uno de ellos logró alquilar una casilla en Villa Unión (ruta 3 kilómetro 28 de la Matanza, provincia de Buenos Aires) y los fines de semana Rosa podía estar allí con sus hermanos. Así recuerda aquel momento:

"Ahí los veía los fines de semana a mis hermanos. Cuando mi hermano Ramón se da cuenta que estoy embarazada, estaría de siete, ocho meses la manda a llamar a mi mamá. Le manda a decir "parece que Rosa está embarazada, se la ve rara, está muy gorda". Pasaron los meses y yo no me daba cuenta, nadie me había explicado, no, no, no, nada. Yo me di cuenta de que estaba embarazada cuando mi patrona me empezó a decir "¿cuándo menstruaste?, ¿cuánto hace que no menstruas?”. Se ve que ella me controlaba o se daría cuenta, no sé, y bueno ahí ella me empezó a decir. Pero ni así me fui al médico, ni ella me dijo anda al médico. Cuando me di cuenta, yo le conté a una amiga que parecía que estaba embarazada y yo sentía los latidos en mi panza, pero esa amiga era chica como yo, quedó ahí, no hablamos más, ni ella me dijo nada, ni yo le dije más nada. Y bueno, mi hermano se dio cuenta y la mando a llamar a mi mamá, le mandó una carta, porque antes era todo por carta. Y cuando llega mi mamá no pregunta si estoy embarazada, nunca me preguntó. Yo tenía vergüenza de mirarla a ella, porque era como que yo le falté el respeto a ella, como que yo fallé, me sentía culpable yo, no la podía mirar a la cara”. (ROSA, 2018, entrevista oral)

Amanda también me contará en detalle los síntomas del embarazo que ella desconocía por completo en aquel momento:

\begin{abstract}
"A mí me daban vómitos pero yo no sabía que estaba embarazada, bruta y media... y el tipo re mujeriego, tenía dos años más que yo, andaba con una y con otra... Yo pienso que él sabía [del embarazo] porque todos en el pueblo sabían, yo recién hace unos años se lo dije, le mandé una carta". (AMANDA, 2014, entrevista oral)
\end{abstract}

Amanda recuerda que en este momento su vida era "un caos" no tenía donde quedarse a dormir porque la relación con su madre era conflictiva sumado a que en ese año, 1976, su padre se enferma y muere. Durante el velorio una amiga de la familia, Aída, que hablaba mucho con su madre le dice: 


\begin{abstract}
“No querés venirte a Buenos Aires a trabajar?” Mi mamá hablaba mucho con esta tipa... yo decía que no, hasta que me convencieron y mi madre dijo: "sí, andate porque yo acá no tengo lugar para tenerte"... Me armaron una valija y me fui, me acuerdo patente al día de hoy que mi madre le dijo: "y llévesela nomás porque qué voy a hacer yo con ella”. Eso nunquita más lo olvidé, pero nunca... y la otra me miraba y me decía: estás gordita, ¿no? estás gorda... Y yo te juro, yo no sabía...". (AMANDA, 2014, entrevista oral)
\end{abstract}

A Amanda la llevaron a Villa Gesell, una ciudad balnearia de la Provincia de Buenos Aires a trabajar como empleada doméstica con la promesa de que Aída volvería, pero no fue así:

“Ella me dejó allá y desapareció del mapa. Era un pasillito donde había una cama y yo lloraba y le decía a la patrona "tráigala a Aída, que venga Aída, porque a mí me duele la panza, me duele la panza" y entra con una cara el hijo de puta un tipo que me parece que lo estoy viendo y dice 'usted tiene un chico adentro de la panza, usted no sabe que tiene un chico' Ahí tenía que fregar los pisos, comer las sobras, lloraba día y noche, día y noche, me tenían encerrada, no podía salir". (AMANDA, 2014, entrevista oral)

Para comprender cómo eran socialmente visualizados los embarazos de estas mujeres y también cómo ellas mismas los han vivido es importante señalar que la naturalización del vínculo materno y la maternalización de las mujeres, tal como ha descrito Marcela Nari (2004), es resultado de un largo y complejo proceso que se potencia a inicios del siglo XX (BADINTER, 1981) en donde las ciencias médicas han jugado un rol decisivo. Así, la gestación se transformó en un proceso semejante a la enfermedad que requería de la presencia médica antes, durante y con posterioridad al parto (NARI, 1995). Para los años 60, en el contexto cordobés, Agostina Gentile, a partir del análisis de expedientes judiciales, ha mostrado el contexto institucional y la vulnerabilidad que rodeaba a las mujeres jóvenes (solteras, pobres, institucionalizadas, mayormente) que daban a luz en los años que Rosa lo hizo, señalando que "el embarazo, el hijo y su entrega eran asuntos femeninos" (2017, p.119).

Otro elemento común que identifiqué en todas las historias de estas mujeres refiere al rol del médico y su poder de acción y decisión sobre sus cuerpos y también sobre el de sus hijos/as. En todas mis entrevistas y en las notas de campo que obtuve ellas relatan no haberse animado a cuestionar la 
autoridad del médico. Así me lo contaba Elsa, una mujer que busca a su hijo nacido en 1978 en la Maternidad Sardá:

\begin{abstract}
"En el momento no me atreví, no me permití pensar que los médicos me estaban mintiendo, y cada vez que yo buscaba y pensaba en mi hijo, yo misma me decía "ey, ey, no empecés a enloquecerte, ya te dijeron que nació muerto" y no me dieron nada [se refiere al certificado de defunción y al cadáver]. Pero ni siquiera yo me lo permití durante muchos años, y uno llora todos los días por eso, es un duelo que nunca cierra, uno aprende a vivir con ese dolor y con esa falta, pero no cierra nunca". (Nota de campo reunión de agrupación Madres en Búsqueda. 5 de marzo de 2017. Ciudad de Buenos Aires) $)^{17}$
\end{abstract}

Irene Palacio Lis analiza las imágenes que históricamente fueron construidas sobre las mujeres como "seres menores de edad, faltos de arbitrio, ignorantes, irresponsables y en consecuencia, precisados de tutela y dirección en el logro de 'objetivos superiores', como tantas veces se explicitó -a veces de una forma brutal- por parte de los médicos, en particular" (PALACIO LIS, 2003, p. 27). Estas y otras representaciones sobre las mujeres pueden ser entendidas también como formas de minorización (FONSECA, 2012) y cosificación. Si bien Rosa, y otras de mis entrevistadas, podían atender a sus hermanos/as, cuidar de otros niños/as y/o realizar tareas de domésticas en diversos lugares, ellas "no podían criar un hijo/a". "No vas a poder", "cómo te vas a ocupar, si no podés mantenerte ni vos", "no vas a poder" eran algunas de las cosas que les decían mientras estaban embarazadas.

Mónica Tarducci sostiene que "se insiste sobre la adolescente embarazada para que lo dé en adopción a una pareja que no puede tener hijos, así, ella puede seguir con la vida "normal" para una joven. En el triángulo de la adopción la madre de origen es la persona "no grata", la que incomoda, sea adolescente caída en desgracia o madre con muchos hijos chicos que mantener" (TARDUCCI, 2008, p. 22). De igual modo, son "demasiado" jóvenes o tienen "demasiados" hijos"18, es decir que quedan por fuera de las "virtudes" que se esperan de una "buena

\footnotetext{
Esta nota de campo de la autora fue tomada en el marco de su trabajo de campo en la Agrupación Madres en Búsqueda durante 2017.

${ }^{18}$ Expresión de cuantificación que hace sentido a la luz de las ideas entorno al modelo de familia nuclear (COSSE, 2010; NARI 2004) que es aquella conformada por una pareja heterosexual y monogámica y cuyo principal fin es la procreación de una cantidad de hijos que posibilite su manutención y crianza.
} 
madre" (TUBERT, 1996). Así, aquellas mujeres que "entregaron" a sus hijos o bien que eran demasiado jóvenes e incapaces para criarlos, se encontraron desplazadas del ideal de moralidad materna y fueron conceptualizadas como "malas madres" o bien como "madres desnaturalizadas" (SALVO AGOGLIA; SAN ROMÁN, 2019) en tanto contravienen el mandato de la naturaleza (PALOMAR VEREA, 2004).

Durante la entrevista que mantuve con Amanda ella relata diversas expresiones proferidas por las personas que intervinieron en el parto referidas a su "incapacidad" para criar a su hijo/a:

"De la casa donde estaba en Villa Gesell me llevan un 31 de diciembre al Hospital Santamarina de Tandil y ahí tienen en un cuartito, me quise escapar pero uno de uniforme me llevó de vuelta a empujones, me decían que para qué quería yo el bebé, que era muy joven, que había gente que necesitaba el bebé. Yo estaba sola, no sabía dónde estaba parada, lloraba, tenía dolores, era un caos todo. Me encerraban con llave y cada tanto venían las 'damas rosadas' que me sacaban a un patio chiquito y yo lo único que había era llorar y pedir que me mandaran a Gualeguay. Las damas rosadas las tengo acá (se toca la frente con su dedo indice)... Son las viejas de mucha plata que no saben qué carajo hacer en la vida entonces se van -dicen- a dar una mano en los hospitales. Esas iban y me hablaban, y me decían estupideces, "que no te pongas nerviosa, que vas a estar bien, espera que nazca tu hijo, que va a quedar acá, que vos no podés andar en la vida con un hijo, que vos no sabés lo que es". Yo quiero que me manden a Gualeguay era lo único que yo decía... Y el momento del parto cuando nace el bebé, yo lloraba, descompuesta, gritaba, a mí me ataron, no veía nada, es terrible, terrible todo, sacan la criatura y yo escuché el llanto del bebé y que me lo sacaron por el costado y se lo llevaron y no lo vi más. Lo llegué a ver así de refilón todo sucio... Yo estaba a la deriva, indefensa, y querían la criatura y yo no me sabía defender. Después de que tuve el nene [sabe que fue un varón] que fue un 23 de abril de 1977 a las 12 del mediodía, me sacaron del hospital y me tiraron en una estación de trenes. No tenía plata, ni ropa y estaba toda roñosa, pasó una chica que me vio los dos días que estuve ahí y me auxilió. Creo que era de Madariaga, esa chica me ayudó y me consiguió un trabajo con cama, hasta que pude juntar unos pesos y escaparme, fui a Buenos Aires y de ahí a Entre Ríos, pero así como llegué me volví, porque no querían saber nada de mí y me vine a trabajar a Buenos Aires". (AMANDA, 2014, entrevista oral)

Después vendrá el matrimonio, sus otros tres hijos y una vida de mucho trabajo. Amanda está separada y relata hechos de violencia con el que fue su 
marido. Ella recién pudo "hablar" del robo de su hijo en el 2000 cuando se lo contó a una amiga que le dijo: "urgente tenemos que empezar a buscarlo, buscalo!".

En los casos que pude relevar en mi investigación una de las regularidades que encontré refiere a la edad. Rosa y Amanda, al igual que muchas de las mujeres que hoy buscan a sus hijos/as, eran jóvenes, en su mayoría menores de 20 años y por lo general en redes familiares de desprotección o conflictivas ${ }^{19}$. Rosa migro de la provincia del $\mathrm{Chaco}^{20}$ para trabajar en el servicio doméstico en Buenos Aires, una práctica usual de los recién llegados migrantes registrada desde finales del siglo XIX y principios del XX (ALLEMANDI, 2015a), donde desde edades muy tempranas varones y mujeres participaban de las actividades económicas de la ciudad. De igual modo, las infancias de Rosa y Amanda estuvieron signadas por el trabajo, práctica que en la actualidad resulta incomoda e incluso alarmante ${ }^{21}$. Así mientras Rosa era "joven” para tener un hijo, no lo era para trabajar en la cosecha de algodón en Chaco o en el servicio doméstico en Buenos Aires, lo que devela que los límites entre infancia y adolescencia están marcados por las diferencias de clase y género.

Como señalaba, la mayoría de los casos que pude relevar son embarazos de mujeres jóvenes y solteras (DI LISCIA, 2002), como Rosa que se embarazó a los 14 años o Amanda a los 17 años, situación que actualmente podría clasificarse como un "embarazo adolescente" (GONGA, 1996). En los años 60 la tematización del embarazo en la adolescencia comienza a ser considerado como un "problema” de salud pública (ADASZKO, 2005). En ese momento se configura una preocupación estatal por las maternidades juveniles consideradas como

\footnotetext{
19 Este análisis también permite pensar la relación de Rosa y Amanda con sus madres (signadas por el conflicto y el maltrato) y cómo las maternidades antes que ideales son reales, situadas y contextuales y que, en muchas ocasiones, se configuran de forma distante y opuesta de la maternidad ideal.

20 Retomando los aportes de Alfredo Lattes en "Esplendor y ocaso de las migraciones internas" Carlos Hudson (2012) señala que entre 1945 y 1960 el 67\% del crecimiento poblacional de la provincia de Buenos se debe a los movimientos migratorios. Y si bien en la provincia de Chaco entre 1947 y 1960 continua el crecimiento la población rural ésta comenzará su éxodo durante el período intercensal siguiente (1960-1970).

${ }^{21}$ Si bien no es objetivo de este trabajo, el caso de Rosa también resulta una invitación para pensar su experiencia en relación al trabajo infantil y para reflexionar en torno a los matices entre lo urbano y lo rural en estos temas. Para un análisis sobre estos a fines del XIX y principios del XX consultar: "Niños sirvientes y "criados": el trabajo infantil en el servicio doméstico (ciudad de Buenos Aires, fines del siglo XIX-principios del XX)” de Cecilia Allemandi (2015).
} 
“inapropiadas"22 y se irán generando propuestas estatales "que han caracterizado, sancionado y construido atributos en cuanto al género y la maternidad, procurando regular sus comportamientos, emociones y deseos" (GAITÁN, 2018, p. 219). El concepto de adolescencia se relaciona con la emergencia de la noción moderna de individuo (ADASZKO, 2005) pero "el carácter universal de la categoría definió a los jóvenes de los sectores más desfavorecidos como adolescentes igualándolos a los de las clases medias y altas, aunque sus experiencias tenían muy poco en común (BOURDIEU, 1990)" (ADASZKO, 2005, p. 43)23. Este punto merece nuestra atención ya que los casos de estas mujeres están marcados por un fuerte componente de clase porque en su mayoría provenían de sectores populares, de modo que no es posible universalizar las trayectorias vitales sin tener en cuenta las estructuras de desigualdad y exclusión y los procesos de vulnerabilización que afectan a adolescentes y jóvenes de los diversos conjuntos sociales.

A continuación, quisiera reponer las circunstancias del robo del hijo/a de Rosa. Ella me contará que vio a la partera en dos oportunidades, en una "consulta" que fue a hacer su madre y luego en el momento del parto y robo de su bebé en la casa de la partera que funcionaba como consultorio clandestino. Cuando su mamá viene del Chaco, al enterarse de su embarazo le dice que la acompañe a lo de una partera porque estaba embarazada y se quería hacer un aborto. Así lo recuerda:

"Bueno, yo la acompañé, ella entró al consultorio de la partera. Y cuando salió la partera me miraba y me sonreía... y yo digo ahí arreglaron todo, ahí arreglaron todo, yo ahí como una tonta afuera y ellos estaban arreglando todo. Ella no me revisó, nada, nada, nada. Mi bebé nació en febrero del 68 pero no me acuerdo bien. Estábamos en la casillita porque ya no podía trabajar, hacía mucho calor, rompo bolsa y la llamo a mi mamá, estaban afuera todos sentados en un patio, y le dije "mire esto", siempre la trate de

\footnotetext{
22 Para un análisis sobre las transformaciones en el universo juvenil femenino en los años 60 consultar Valeria Manzano (2017). A partir de un resonante caso sobre la desaparición de una joven en 1962, la autora realiza una sugestiva reflexión acerca del "pánico" en torno de la moral sexual de los jóvenes y los límites de la nueva libertad de movimiento de la época. Si bien su análisis se sitúa en los 60, en la ciudad de Buenos Aires y en las clases medias, es menester considerar que la noción de pánico moral (COHEN, 2009) es una potente construcción de larga duración.

${ }^{23}$ La adolescencia, en tanto fenómeno social, tiene distintas variabilidades, de clase social y también histórica y cultural como tempranamente señaló Margaret Mead (1939) a partir de su trabajo etnográfico en Samoa
} 
usted, hasta ahora. Y ella me dice "ah sí, ah, bueno espera un ratito", ni siquiera me dijo te tenés que limpiar, tenés que... nada, yo no sabía lo que me estaba pasando. Y pasan dos horas y llega un coche negro y baja la partera, esa mujer tan bonita pero con alma de diablo, ella era amable, pero después que nació el bebé me trató agresivamente. Ella me dijo “¿te acordás de mi?” y yo la mire a mi mamá y ahí viene lo peor... (se emociona y llora). Y me subí al auto y nadie fue conmigo, estaban todos, estaban todos y nadie fue conmigo, esa misma noche nació el bebé y cuando yo gritaba la partera me la traía a la hija y me decía: "tiene tu edad y está muy asustada de verte como gritas". Y cuando nació el bebé no me lo dejó ver, no me lo dejó ver (llora). No lo pude tocar, yo pregunté qué era y me dijo que "no tenía derecho de saber". Ella lo recibió al bebé y estaba otro hombre que estaba atrás mío. Cuando salió el bebé yo me quise enderezar y el señor me apretó acá (señala su pecho) y me dijo que me acueste. Yo escuchaba que lloraba y después escuche el llanto cuando se lo llevaba. Y yo gritaba que me lo traigan, yo gritaba pidiendo por mi bebé y ella me decía "calláte que te voy a mandar presa, si seguís gritando voy a llamar a la policía y la van a llevar presa a tu mamá y a vos". Y yo le creí, no sabés... yo viví con miedo, viví con miedo porque después yo conozco a mi marido y a los dos años nació mi hijo Rolando y yo salía a la calle con miedo que me lo vayan a sacar, veía una mujer rubia [como la partera] y salía corriendo. Sabés cuando terminó el miedo, cuando apareció Luz [una de las mujeres vendida por la partera en 1978 y que la denunció]. Ahí perdí el miedo porque siempre viví con miedo de que ella aparezca y nos haga algo... Y no sé cuánto tiempo estuve ahí en el consultorio, ella me durmió creo porque yo gritaba mucho que me entreguen mi bebé. Cuando me desperté me llevaron ellos, pero no me acuerdo en el momento que me dijo te tenés que ir. Y volví a la casilla y no se habló nada de nada de nada. Yo tenía una cunita de hierro que me habían regalado y donde iba me veían embarazada y me daban ropita, y yo la iba lavando y guardando en la cunita... Y cuando volví ya no estaba más la cunita, le pregunté a mi mamá y me dijo que le había dado a la vecina de enfrente (llora). Y yo volví rápido a trabajar y la señora me preguntaba por el bebé y mi mamá me dijo que si preguntaba le tenía que decir que había muerto, pero la señora nunca me creyó". (ROSA, 2018, entrevista oral)

Poco después de tener a su bebé Rosa conoció a Lisandro, su marido, e incluso recuerda que "todavía tenía los pechos llenos de leche". Tuvieron 7 hijos, Rolando el mayor, que nació en 1970 y luego todas mujeres. Rosa y Lisandro siguen juntos hasta hoy y a ella se le ilumina la cara cuando habla de él y de su familia. En su relato fue recurrente la palabra "miedo" ante las amenazas que tuvo en el momento del parto, así como tiempo después. 
"Yo le conté Lisandro todo lo que me había pasado, pero no hicimos nada por miedo. Nos fuimos a vivir a Santiago del Estero en el 73 porque él es de allá y los padres le habían conseguido trabajo en el ferrocarril. Pero nunca pude olvidar... Ahí conocí a mi suegra, una mujer tan buena, ahí conocí lo que es tener una familia que te apoye... Mi familia era muy distinta, mi papá era alcohólico y mi mamá no era compañera de él, mi mamá siempre fue muy dura... Yo siempre pienso qué hice en la vida para que mi mamá sea tan mala conmigo, siempre fue así, por eso me mando cuando tenía 12 años. Vos no sabés como yo mezquino a mis nietas. No las mando a comprar cuando se hace tarde, tengo terror de que les pasé algo y así las cuidé a mis hijas. Mi hijo mayor tiene 48 años y le duele algo y me llama, yo tenía 12 años y no tenía a quien preguntarle y eso duele mucho, duele muchísimo (llora)". (ROSA, 2018, entrevista oral)

En su conmovedor relato llega el momento del después, del paso del tiempo, casi 50 años, y el momento del juicio donde fue una testigo clave, de volver a ver a "esa mujer" pero esta vez en "el banquillo de los acusados" como me dijo. Rosa relata cómo supo del juicio que estaban llevando adelante tres mujeres vendidas por la partera en 2012, entre ellas Luz, una joven nacida en 1978 con la cual Rosa ha trabado un fuerte vínculo afectivo:

"Yo un día estaba viendo el noticiero en Telefé y la veo a Luz que estaba diciendo que todos los chicos que tengan en su partida de nacimiento la firma de la partera, que se hayan sentido raros en la crianza, que se acerquen a un lugar y daban un teléfono. Una de mis hijas estaba viendo y anotó y la llamó y al poco tiempo empecé a conocerlos a todos y participé de su juicio. Y creo que pude gritarle a la partera todo lo que había hecho. Porque ella dijo que ella agarraba algunos chicos cuando encontraba a las madres que dormían con los perros, entonces como esas chicas no tenían como criar los chicos los agarraba, lo dijo en el juicio. Ella dice que no me conoce... Yo la vi cómo ella me sacó el bebé y se lo quedó y ni siquiera me dio derecho a saber si era nena o varón. Mi hijo no tiene cara, yo sé que tengo un hijo pero no tiene cara, para mí siempre fue un varón, pero no lo sé. Yo siempre pienso, ¿no? ella me podría haber matado, yo podría haber muerto en el parto porque era muy chiquita, no había nadie, nadie para ver qué es lo que me estaban haciendo, tenía 14 años, de mi familia no había nadie, estaba yo y ella y ese señor, que para mí él se lo quedó, porque para qué estaba presenciando el parto, que sé yo". (ROSA, 2018, entrevista oral) 
Culpa, vergüenza y abandono: disciplinamientos morales y acceso a la justicia

Ahora bien, para comprender cómo estas mujeres deciden llevar su demanda al terreno judicial resulta iluminador el caso de Rosa ya que, tal como fue relatado por los activistas nucleados en torno a la causa de la partera, fue una "bisagra", un antes y un después en la causa, en tanto ella es la primera madre que se presenta denunciando que esta partera le robo su hijo/a. En el juicio Rosa fue "una pieza clave" porque permitió dar cuenta de la trama de robo y venta de niños que la partera realizaba en su consultorio clandestino de González Catán, es decir como ella robaba niños, tal el caso del hijo de Rosa y como los vendía, como fue el caso de Luz que fue vendida por el valor de un auto cero kilómetro ${ }^{24}$, tal como declaró en la causa judicial y en las entrevistas que le realicé (GESTEIRA, 2016).

Rosa dice que si bien fue importante el juicio porque pudo "gritarle en la cara lo que hizo" a la partera, también "la enfermó". Relata que le salieron pólipos en el intestino, durezas en todo el cuerpo, y sintetiza "creo que remover todo me enfermó mucho". Luego de la condena en 2012 se inició un segundo juicio donde Rosa es querellante junto a otros cinco hombres y mujeres vendidos por la partera. En este segundo juicio citaron a declarar a los hermanos de Rosa, quienes la llamaron para decirle que "era una mala mujer, que porqué tenía que mover todo esto ahora, que su madre es vieja". Rosa se angustia por el silencio y las versiones cruzadas de su familia:

"Toda la vida les pregunté y siempre hubo enojos, malos tratos. Me decían "como ibas a criar a un hijo si no te podías mantener ni vos” (llora), eso me decía mi mamá. Y antes que murió mi papá lo

\footnotetext{
${ }^{24}$ Para quienes tienen la certeza de que fueron comprados al nacer, el dinero (SIMMEL, 1976) es percibido como un elemento disruptivo e impuro puesto que les resulta intolerable haber sido tratados como objetos de valor económico, es decir haber tenido un precio, en una sociedad en donde "los niños no tienen precio" (ZELIZER, 1992). De un modo similar, en la narración de Rosa emergen conceptos propios del mercado: venta, dueño, abundancia (de quienes tienen muchos hijxs), carencia (de quienes no pueden tener hijxs y procuran hacerse de ellos por medios ilegales), es decir, un conjunto de valores propios del intercambio de objetos. De este modo también para el caso de estas mujeres (al igual que Luz y los hijos que buscan) es posible pensarlas como objetualizadas en tanto ellas (y sus hijxs) ingresan, forzada y violentamente, en un circuito de mercancía, de compra-venta y propiedad. Y si bien, como nos recuerda Bourdieu (1998), la esfera de lo familiar suele concebirse en oposición a la del mercado, estos casos develan una profunda y extendida porosidad e interconexión entre ambas.
} 
estuve cuidando, y él me dijo que mi mamá sabía, pero ella dice que mi papá sabía, así que ya me cansé de ellos (llora)... Yo pienso que mi mamá y mi hermano saben, que mi mamá hizo un arreglo con la partera, pero sin plata de por medio porque seguimos siendo pobres". (ROSA, 2018, entrevista oral)

La semana anterior a nuestro encuentro Rosa recibió una noticia de su abogado, el Cuerpo Médico Forense dictaminó que la partera (actualmente de 86 años y con prisión domiciliaria) por su edad avanzada y el deterioro de su salud no está en condiciones de afrontar un segundo juicio. Esta situación la angustia profundamente a Rosa que me comenta: "Yo hubiese querido estar muerta, porque yo tenía un cachito de esperanza de que ella se arrepienta estando vieja y diga (llora) la mamá de Luz es esta persona, tu hijo es aquel”.

Rosa aún espera que su familia, especialmente su madre, le digan lo que sucedió con hijo/a y también que le pidan perdón.

\footnotetext{
"Yo tengo esperanza que mi mamá antes de morir me diga "perdóname, lo hice porque eran muchos ustedes, porque éramos pobres”, que me diga, sí, lo hice. La última vez que fui le dije que la perdonaba... Yo le dije: me hubieras mandado a trabajar, yo te daba toda mi plata pero me hubieses ayudado con mi bebé y ella nada, no me contesta... Como te puedo decir, mis hijas me dicen "me haces falta" o frases lindas, y a mí no me saldría con ella, que podés ponerle a una persona que te saca lo que más querés (llora), que le podés decir... Y esto que me pasó a mí es un dolor en el alma que me va matando de a poco... Yo creo que al que no le pasó no sabe el dolor". (ROSA, 2018, entrevista oral)
}

Amanda también acudió a la justicia por el robo de su hijo. En 2007 inició una causa judicial en la Fiscalía Federal de Azul y viajó varias veces a Tandil para hacer averiguaciones, especialmente en el Hospital Santamarina. Durante la entrevista enfáticamente me dijo: "yo tengo todo" y me mostró una carpeta grande repleta de papeles todos prolijamente guardados en folios y documentos de todo lo que hizo en la búsqueda, entre ellos, un afiche con el que "empapeló Tandil" y todos los boletos de colectivo de sus viajes a Tandil. Una de las cosas que logró conseguir en sus viajes fue el libro de parto: "Cuando yo lo recibí me quería morir y lloraba a mares, saqué veinte mil fotocopias. No es la partida de nacimiento, es el registro de parto que confirma que yo estuve ahí y que fue un varón. Yo tengo todo eso guardado y he dejado fotocopia en el juzgado de Tandil". 
En 2014 la causa no había avanzado, pero llamaron a declarar a sus hermanos, al padre del bebé, (su madre había fallecido) y hasta el momento de nuestra entrevista no habían encontrado a Aída. Sin embargo, Amanda tenía esperanzas de que hubiera una resolución positiva de su caso.

La presencia de estas mujeres que buscan a sus hijos/as robados/as y Llegan a la justicia a dar testimonio, irrumpe en las burocracias judiciales -espacio marcadamente masculino- para revelar una serie de hechos que, en mayor o menor medida, se relacionan con su condición de mujeres, con la situación de pobreza y en algunos casos con la edad. En otras palabras, se trata de una jerarquía social compuesta por clase, género y edad, que se torna un prisma indispensable para interpretar y comprender este tipo de casos. Asimismo, es importante preguntarse por qué llegan en este momento estos testimonios, por qué cada vez son más las mujeres que denuncian el robo de sus hijos/as en hospitales públicos y clínicas privadas en donde no les dieron la documentación del bebé ni la posibilidad de ver el cuerpo, entre otros elementos que son recurrentes en estos casos.

Durante las entrevistas que pude realizar con estas mujeres para mi trabajo posdoctoral advertí que durante muchos años ellas callaron, algunas sintiendo culpa y responsabilidad por lo sucedido, o siendo acusadas de "locas" porque fantaseaban con algo que "no era así" porque el "bebé estaba muerto" o bien porque eran acusadas de "entregadoras" y/o "malas mujeres". Lo que intento señalar es que durante muchísimo tiempo estas mujeres creyeron estas adjetivaciones, como Rosa me decía "yo le creí" en referencia a que la culpable de la situación era ella y por eso la partera podía mandarla presa y que, en consecuencia, ella "no tenía derecho" sobre ese bebé.

En los casos de las mujeres que denuncian el robo de sus hijos/as y acceden a la justicia o se están comenzando a organizar hay un movimiento que va de lo privado a lo público, de lo individual a lo colectivo (PITA, 2010), pero también de lo clandestino a lo legal. El caso de Rosa se desplaza desde la clandestinidad de ese consultorio donde fue robado su hijo a los Tribunales donde da testimonio de lo ocurrido allí hace cincuenta años. Así el "dar testimonio" les permite resignificar los hechos que tuvieron lugar en el momento 
del robo, ahora "puede" contarlo y ello responde, entre otras cosas, a que las concepciones, sentidos e ideas sobre la maternidad, la familia y la infancia han cambiado desde los años 60 a esta parte. En este sentido, cabe recordar que el modelo de moralidad materna (NARI, 2004), implicó la dispersión de mensajes coercitivos y prescriptivos sobre cuál era el modo "correcto" de criar a los niños y también sobre cómo y cuándo concebirlos. Si bien, durante los años 60 y 70 el destino de las mujeres era el matrimonio y la maternidad, ello acontecía según normas, regulaciones y principios legales y sociales, por ello los embarazos de estas mujeres (adolescentes, solteras, sin recursos) contrariaban el ideal normativo de la familia basado en el matrimonio legal, el poder patriarcal y el parentesco legítimo (COSSE, 2010)25. Es por ello que, de diferentes maneras, embarazos como el de Rosa debían ser administrados y encauzados, al igual que esas mujeres a las que además "se les hacía un bien” o "iban a escarmentar y aprender cómo hacer bien las cosas la próxima vez", e inclusive "podían seguir teniendo otros hijos, así que no era 'tan' terrible”, tal como me contaron que les han dicho enfermeras y médicos. En efecto, todo lo vivido por Rosa y Amanda remite a prácticas que perseguían un disciplinamiento del cuerpo y la moral femenina (DE PAZ TRUEBA, 2007; GENTILI, 2017, 2018). Maternidades que debían ser disciplinadas, mediante la coacción para la entrega del bebé o el robo y la sustitución de identidad. Para Rosa o Amanda, y otras de mis entrevistadas, el robo de su hijo perdura como "marca de por vida", como un "dolor que no se borra", como algo que las va matando de poco o las enferma, como me dijeron. Por ello es posible advertir una singular forma de disciplinamiento moral que perdura en el tiempo bajo una serie de sentimientos y emociones recurrentes en estas mujeres "la culpa, la locura, la vergüenza, la deshonra”. Amanda durante mucho tiempo "creyó que ella había hecho algo mal" hasta que un grupo de psicólogos "le sacó eso de la cabeza” y pudo denunciar y comenzar la búsqueda.

\footnotetext{
25 De un modo similar, en su investigación con expedientes judiciales entre 1890-1910 sobre aborto, infanticidio y abandono, Julieta Di Corleto (2018), revela que las mujeres que llegaban a la justicia eran en su enorme mayoría del servicio doméstico (con cama o habitantes de conventillos) y cómo esos embarazos también iban en contra de los códigos de moral sexual de la época. Al mismo, su trabajo también revela cómo la doble moral sexual construía a esas mujeres como cuerpos disponibles para los patrones e hijos de sus patrones.
} 
En varios pasajes de su relato Rosa hizo referencia a la culpa ${ }^{26}$ y la vergüenza que sintió cuando estaba embarazada. Claudia Fonseca, en una investigación sobre madres de nacimiento de hijos que buscan sus orígenes agrupados en la organización Filhos adotivos de Brasil, advierte que "A vergonha não se remetia à gravidez em si (afinal de contas, a maternidade era o destino de toda mulher) nem à solteirice em si [...]. Era a combinação dos dois - a conotação de relações sexuais fora do casamento - que suscitava escândalo" (FONSECA, 2012, p. 21). En efecto, al contar, narrar, poner en palabras, "testimoniar", Rosa puede resignificar su propia maternidad, aquella por la que sintió culpa, responsabilidad y vergüenza hoy es el motor para buscar a su hijo/a y actualmente tiene la certeza que sí "tiene derechos" y que si hay culpables en esta historia, son la partera y sus familiares, como cómplices de la entrega de su bebé. Es decir que aquella maternidad considerada como fuera de lugar (FONSECA, 2012), que estaba por fuera de las formas legítimas de construir-y concebir- la familia y el parentesco y que tuvo que ser administrada y disciplinada por sus familiares y por la partera (adultos mayores), ahora es una maternidad que encuentra un lugar en la Justicia y se configura como una maternidad que fue violentada en sus derechos, una maternidad legitima.

De esta manera, la condición de "madre" supone un tipo de autoridad moral que en nuestro país se relaciona con el activismo político y jurídico que han llevado adelante Madres y Abuelas de Plaza de Mayo (VILLALTA, 2012) y también con el activismo de los familiares de las víctimas de la violencia policial (PITA, 2001)27. Para el caso brasilero de madres que sus hijos/as fueron asesinados por la policía militar de Río de Janeiro, Adriana Vianna y Juliana Farias sostienen que "o acionamento da condição de mãe como elemento de autoridade moral em atos políticos nos fala de trânsitos relevantes em cenários contemporâneos:

\footnotetext{
${ }^{26}$ La culpa es un sentimiento recurrente en todos los casos que releve. El binomio madre-hijo fue cimentado sobre concepciones médicas y también religiosas, así el instinto maternal (NARI, 1995, 2004) y puntualmente a la imagen de la madre abnegada se la puede vincular al ideal de madre que representa María en donde el sentimiento de culpa adquiere centralidad. En el caso de Rosa la culpa aparece en la autopercepción de su maternidad, incluso la culpa se reedita con la muerte de su segundo hijo, como si esa muerte fuera un "castigo divino" por aquel hijo robado que no supo cuidar, en palabras de Rosa: "yo pensé que Dios me estaba castigando por tener un hijo y no saber a dónde está".

${ }^{27}$ Activismos que están atravesados por experiencias familiares traumáticas, donde la familia (y la pérdida violenta de un familiar) se torna agente legitimador de la construcción de la demanda al Estado y es nodal en la constitución de estos y otros activismos surgidos más recientemente.
} 
entre dor pessoal e causas coletivas; entre sofrimentos e direitos; entre formas e dimensões distintas do luto, aqui tomado como processo inextricavelmente individual e socia" (VIANNA; FARIAS, 2011, p. 83).

Ahora bien, la presencia de estas mujeres que buscan en las demandas de los hijos/as que buscan sus orígenes y específicamente la presencia de Rosa en el juicio a la partera, condensa dos cuestiones importantes. Por un lado, como señalé, Rosa se vuelve "evidencia”, es decir, su historia, su cuerpo, su dolor y su búsqueda son la "prueba" de la trama del robo y venta de niños que ocurría en los consultorios clandestinos de la partera. Y por otro lado, Rosa y Amanda y las madres que buscan, representan la esperanza de cientos de personas que buscan a sus madres y que usualmente deben confrontarse a frases "para que buscas, si ya sos grande, seguro tu mamá te abandono", entre muchas otras frases similares.

Al respecto durante la entrevista Rosa me dirá:
"Yo pienso que si mi hijo se crio sabiendo que fue regalado qué debe pensar de la madre... debe pensar que soy una mala mujer, para regalar un hijo uno tiene que ser malo, malo... (llora)... Pero bueno, yo sé que no fue así... y si lo llego a encontrar quisiera que me deje que lo toque (llora), yo siempre digo lo mismo si él no me quisiera ver por lo menos que me deje que lo acaricie un poquito y ya está, ya cumpliría. Y bueno, que se entere de todo lo demás, como fue que me lo sacaron... Y con lo del juicio me cambió todo a mí, sabés? A mí me hace bien encontrarme con ellos (hijos e hijas que buscan), sabés por qué, porque yo antes pensaba que si lo llegaba a encontrar sería una persona rechazada, despreciada, pero ellos me hicieron sentir que no, me hicieron sentir eso, eso me da esperanza". (ROSA, 2018, entrevista oral)

Tal como se desprende del relato, el abandono aparece como un gran temor que estas personas deben enfrentar, tanto de las madres, como de los hijos e hijas que buscan sus orígenes, ya que muchas veces el "abandono" emerge como argumento en las narrativas que construyen quienes los criaron. De este modo la historia de Rosa y de tantas otras madres que se están organizando, les permite desarticular la hipótesis del abandono o, al menos, cuestionarla como la "única” explicación posible. Si bien, hasta el momento del encuentro con la madre biológica resulta imposible saber cuáles fueron los motivos de la separación o entrega, la presencia de "las madres que buscan" coloca a los 
buscadores en otro lugar. Es decir, dota de sentido a sus búsquedas y permite complejizar la historia detrás del "supuesto" abandono en la medida en que estas mujeres relatan, en su mayoría, que fueron coaccionadas a entregar a sus hijos/as o directamente que se los arrebataron sin mediar documentación alguna (CARDARELLO, 2009) ${ }^{28}$, ni poder ver el cuerpo del bebé.

Al respecto de la noción de abandono resulta iluminador el aporte de Claudia Fonseca: "a palavra "abandono" carrega conotações de uma rejeição emocional, como se a entrega do filho fosse uma escolha consciente das mães em questão. Hoje, pesquisadores enfatizam o quanto a mulher que consente dar o filho em adoção foi, ela mesma, "abandonada" - pelo companheiro, pelos pais e pela sociedade" (2012, p. 17).

No quedan dudas de los múltiples abandonos de algunas de estas mujeres, como Rosa, desde su dura infancia cosechando algodón, la venida a Buenos Aires sola con doce años, el embarazo del cual ni siquiera era consciente, el parto al que nadie la acompañó y el silencio posterior de su familia. Y por supuesto la figura del padre del bebé que le mintió en su nombre y a quien cuando buscó no pudo encontrar ${ }^{29}$. En nuestra entrevista la figura del padre del bebé no emerge en su relato, en efecto durante su narración no lo nombra hasta que yo, cuando había pasado más de una hora y media de grabación, se lo pregunto y me responde:

"Era un señor que trabajaba en una obra de construcción, pero lo vi dos o tres veces nada más. Era mucho mayor que yo. A mí me gustaba él. Yo siempre pensé que capaz que era casado por eso no me buscó más. Tampoco lo busqué cuando estaba embarazada... Yo pensé que se alejó porque... (se interrumpe) era chica también... (se emociona y llora) no entendía, creo que seguramente no me interesó, siempre me arrepiento porque

\footnotetext{
28 A partir de analizar un movimiento de madres de sectores populares de San Pablo (Brasil) surgido en 1998 que exigía la revisión de los procesos judiciales que condujeron a la adopción de sus niños/as (a familias extranjeras y brasileñas), Andrea Cardarello (2009) indaga las condiciones en que esas adopciones tuvieron lugar. Si bien en estos casos había "documentación", la autora señala cómo algunas de estas mujeres firmaban documentos sin saber lo que estaban firmando porque eran analfabetas o porque no entendían el lenguaje jurídico de esos documentos

${ }_{29}$ Tal como señalaron Irene Salvo Agoglia y Florencia Herrera, la figura del padre ha sido construida históricamente sobre la base de la incertidumbre. Las autoras señalan que los hombres/padres han estado subrepresentados en los estudios sobre los procesos reproductivos y la crianza de los hijos y puntualmente para el caso de la adopción la figura del padre biológico se ha invisibilizado y estereotipado (Salvo Agoglia y Herrera, 2020).
} 
capaz que teniendo un respaldo no iba a pasar eso. Una vez fui a la obra, antes de enterarme que estaba embarazada, y pregunte por él y un vecino me dijo que me había mentido en el nombre, porque me dijo "acá no hay ningún hombre con ese nombre y le explique, más o menos, cómo era y me dijo "te mintió el nombre", me dijo que no sabía nada”. (ROSA, 2018, entrevista oral)

En ese sentido también resultan reveladoras las declaraciones que hizo el padre del hijo de Amanda cuando lo citaron a declarar en la causa judicial, ella estaba muy angustiada mientras narraba este episodio:

"El fiscal me leyó lo que declaró 'el señor declaró que él no sabe quién es usted'. Yo te imaginas, mi corazón debe ser de hierro, cuando me leyó eso... Mi gran sufrimiento es encontrar a mi hijo, lo que piense él no me interesa. La mujer de él y todos ya se enteraron... Porque tienen miedo, porque allá son muy materialistas y por un ladrillo matan, piensan en la plata, piensan que esto lo hago por plata... Cuando declaró él lloré a mansalva, yo no lo podía creer". (AMANDA, 2014, entrevista oral)

La historia de Amanda, además del abandono del padre de su hijo, al igual que la de Rosa, da cuenta cómo en diversas circunstancias, desde su infancia, fue abandonada y desprotegida.

De la violencia y el silencio a la construcción de demandas de justicia

Los casos abordados en mi investigación además de acercarnos a la experiencia histórica de las mujeres y permitirnos conocer los sentidos sobre maternidad, familia, abandono en los años 60 y 70, también nos convocan a reflexionar en torno a temas que, en la actualidad, se han colocado de forma inédita en la agenda pública y en el sentido común argentino, por ejemplo, el debate en torno a la despenalización del aborto ${ }^{30}$. Revisando el material etnográfico que produje y las entrevistas que mantuve con estas mujeres a la luz de las discusiones que se dieron en ocasión de la sanción de una ley, surgía la

\footnotetext{
30 El proyecto de Ley de Interrupción Voluntaria del Embarazo (IVE) en Argentina fue elaborado en 2006 por la Campaña Nacional por el Derecho al Aborto Legal, Seguro y Gratuito. Sin embargo, en los últimos años el tema ha adquirido una notable repercusión y en 2018 tomó estado parlamentario cuando se trató la ley de legalización en el Congreso Nacional, si bien la cámara de diputados aprobó con media sanción la ley, el senado voto en contra. En Argentina existen dos posturas enfrentadas respecto al aborto, quienes están en contra (conocidos como Provida utilizando como símbolo un pañuelo celeste) y quienes apoyan la despenalización (Campaña por el Aborto Legal, Seguro y Gratuito, quienes utilizan un pañuelo verde).
} 
pregunta respecto a qué hubieran hecho si el aborto hubiera sido legal, gratuito, seguro, es decir, si el aborto existía como una opción real, concreta y no culpabilizante sobre los cuerpos de las mujeres. Si bien resulta complejo esbozar respuesta alguna, entiendo que las trayectorias de vida de estas mujeres aportan al debate en la medida en que exponen de manera cruda y cruel el poder que se ejercido sobre el cuerpo femenino y en este caso también sobre los hijos/as. La imposibilidad de decidir sobre el propio cuerpo es un elemento sugestivo de estos casos y ha sido un eje central en el debate por la despenalización.

Igualmente, estos casos también encuentran relación con la ley de Educación Sexual Integral (ESI) de 2006 que supone acceder a información sobre los cuidados relativos a un ejercicio pleno y consciente de la sexualidad (MORGADE, 2015). Rosa no tuvo información de ningún tipo, por ejemplo, no sabía que era la menstruación, ella pensaba que la sangre era porque se había lastimado:

"La primera vez que tuve la menstruación lloré un montón, porque el día anterior había estado andando en bicicleta con los chicos de mi patrona y me golpeé y pensé que me había lastimado adentro. Se lo comenté a mi patrona y me dijo "eso es de todas las mujeres, eso es todos los meses y de todas las mujeres". (ROSA, 2018, entrevista oral)

Amanda, por su parte, le asigna una valoración positiva al "saber", es decir a la importancia de "no ignorar", revisando su propia historia en nuestra entrevista advierte que "muchas cosas le pasaron por ignorancia". En este sentido, en su narración también coloca otro momento traumático el de su primera menstruación, así lo recuerda: "llegó el momento que me indispuse y yo gritaba de dolor, no sabía qué carajo me pasaba, y todo así...no sabía ni la hora...”.

De este modo, la menstruación, el embarazo y el parto, considerados "hitos fundantes" de la femineidad eran desconocidos por Amanda y me contará con vehemencia cómo llevó a su hija el ginecólogo prontamente para que le expliquen y que no pase lo mismo: "Cuando mi hija tenía 10, 11 años agarré y me fui a buscar una médica que me atendía, una ginecóloga y le dije doctora "por favor quiero que le explique todo porque no quiero que le pasé lo que me pasó a mí..." 
Eugenia Tarzibachi (2017) sostiene que durante el siglo XX el cuerpo menstrual fue ocultado porque provocaba vergüenza. En el caso de Rosa y también Amanda y de otras mujeres que entrevisté, que mencionaron lo mismo, además de la vergüenza cultural sobre la menstruación que atravesaba todas las clases sociales, cabe destacar que ellas provenían de los sectores más vulnerables de la sociedad, sin acceso a la escolaridad y a la salud.

Rosa no supo cuando estaba embarazada, tampoco cuando "rompió bolsa”, y no sabía qué tenía que hacer durante el parto, una serie de episodios que en conjunto dan cuenta de la desigualdad y la ausencia de información y las formas de violencia que ello supone. Por eso cuando en nuestra entrevista hablo con Rosa del debate por el aborto, de la lucha del Ni una Menos ${ }^{31}$ y de la ESI, ella me dice que "todo eso está buenísimo". Todo "eso" que ella no supo y que la llevó a creer durante muchos años que era la culpable de no estar con su hijo/a y que "no tenía derecho" saber el sexo, ni a tocarlo y, por ende, tampoco tenía derecho a reclamar.

También las historias de estas mujeres nos llevan a pensar sobre las formas actuales de comprender el embarazo y el parto y los derechos que tenemos las mujeres las mujeres al respecto. Me refiero puntualmente a la categoría de violencia obstétrica que se entiende como el trato deshumanizado del personal de la salud que comprende desde la gestación hasta el posparto. La violencia obstétrica es una forma de violencia de género (FELITTI, 2011). Estas formas de compresión y conceptualización del embarazo y el parto se presentan como elementos disponibles para nominar aquello que en algún momento quedó reducido al miedo, al horror, la culpa y la vergüenza, pero que actualmente es posible de comprender y de nombrar de otra manera en tanto formas de violencia ejercidas contra las mujeres. De este modo, las historias de vida de estas mujeres, que intenté reconstruir durante mi investigación posdoctoral, ponen de relieve la magnitud de las políticas integrales de educación sexual y procreación responsable en tanto derechos humanos que permitan garantizar

\footnotetext{
31 Ni una menosfue una consigna que surgió en Argentina en el año 2015 desde un movimiento feminista que lucha para contra la violencia hacia las mujeres enfatizando en los femicidios en tanto consecuencia más grave y visible. Por sus efectos, la primera movilización que llevo la consigna "Ni una menos" es considerada como un punto de quiebre y de inicio/apertura del movimiento de mujeres en tanto movimiento social específico.
} 
los derechos sexuales y reproductivos en las trayectorias vitales de las mujeres. En este sentido, la violencia sexual ejercida hacia las mujeres y su consiguiente naturalización resultan elementos clave para intentar comprender la complejidad de estos casos.

Por último, para comprender el surgimiento de la demanda de estas mujeres y por qué actualmente se están dando las condiciones sociales para la escucha de estos problemas es preciso examinar las formas en que se configuraron los Derechos Humanos en nuestro país y el singular lenguaje que devino de este proceso. La labor de Madres y Abuelas de Plaza de Mayo en la búsqueda de justicia por la desaparición de sus hijos e hijas y la búsqueda de sus nietos/as apropiados/as criminalmente durante la última dictadura cívico militar (REGUEIRO, 2013; VILLALTA, 2012), ha generado un repertorio discursivo que estas nuevas formas de activismo retoman en la construcción de sus demandas. También el movimiento feminista y las luchas asociadas a los derechos sexuales y reproductivos de las mujeres han generado su propio repertorio discursivo, al tiempo que ofrecen una clave interpretativa para configurar las demandas de las mujeres que denuncian el robo de sus hijos/as. De este modo, estas nuevas formas de activismo se valen de estos variados repertorios discursivos, es decir una serie de palabras y categorías (apropiación y robo de niños, vulneración del derecho a la identidad, violencia de género, violencia obstétrica, entre otras) que resignificadas les permiten nombrar, describir e interpretar el pasado y esos hechos traumáticos que durante muchísimos años no pudieron comprender o que fueron como una "pesadilla", tal como dijo Rosa en su testimonio judicial. Así, el lenguaje de derechos se revela como un recurso fértil para interpretar los hechos del pasado (robo de sus hijos/as) e interpelar a la sociedad acerca de su gravedad otorgando legitimidad a la demanda de estas mujeres.

Así, en las historias de mujeres que les robaron a sus hijos/as que pude conocer en mi investigación y deciden iniciar una búsqueda y reclamo, se conjugan dos escenas, aquella que vivida con el robo de sus hijos/as y una otra escena de transformación de esa experiencia en un reclamo y una acción política, en una demanda legitima a partir de una resignificación de la experiencia que fue posible a partir de un cambio discursivo y social. 


\section{Reflexiones finales}

En este artículo describí y analicé en profundidad las historias de Rosa y Amanda y retomé otros casos que he relevado, porque funcionan analíticamente como un puente hacia el pasado. Ello así, en tanto las historias de estas mujeres rememoran sucesos ocurridos hace treinta y cuarenta años atrás y en ellos es posible acercarse a las ideas, sentidos y nociones sobre maternidad, familia, identidad y abandono vigentes al momento en que a estas mujeres les robaron a sus hijos/as durante fines del 60 y comienzos de los 70 .

Por ello quisiera sugerir que estos casos revelan la historicidad del fenómeno del robo de niños y niñas en Argentina al tiempo que lo inscriben en la larga duración, ya que historias semejantes a la de Rosa pueden encontrarse a finales del siglo XIX y principios del XX en las trayectorias de mujeres jóvenes y solteras que trabajaban en el servicio doméstico y quedaban embarazadas, algunas incluso por sus patrones en las casas donde eran "colocadas" (VILLALTA, 2012; AVERSA, 2014; FREIDENRAIJ, 2015). Como señalé, durante el siglo XX, puntualmente para los años sesenta, resulta sorprendente la similitud de casos como el de Rosa y Amanda con los analizados por Agostina Gentili $(2017,2018)$ en expedientes judiciales de guarda de la ciudad de Córdoba entre 1957 y 1974 "hacia los años sesenta la madre soltera era la principal protagonista de los relatos judiciales de la adopción, figura delineada como una mujer joven y pobre que no estaba junto al padre del niño o la niña que traía al mundo. La ilegitimidad de esos nacimientos pesaba por las dificultades de crianza en situaciones de precariedad económica vividas en soledad y los prejuicios que recaían sobre esas experiencias" (GENTILI, 2017, p. 118). En diálogo con estos trabajos históricos sobre mujeres jóvenes y de sectores vulnerables que fueron criadas, colocadas, centralmente, en el servicio doméstico, lo que me interesa destacar, a luz de los casos que pude conocer en mi investigación, es que ciertas trayectorias de vida de mujeres jóvenes, pobres y, en ocasiones, migrantes, y ciertos fenómenos sociales, como la circulación coactiva y el robo de niños y niñas, perduran en nuestra sociedad, con matices y diferencias, desde hace al menos dos siglos.

Ahora bien, como fue señalado, las historias de las mujeres que buscan a sus hijos/as robados/as dan cuenta del entrecruzamiento entre las dimensiones 
de clase, género y edad y son evidencia también de la larga duración de la triple subordinación de clase, género y edad que han padecido estas mujeres. Asimismo, ponen de relieve cómo en las prácticas de circulación coactiva de niños y niñas los entornos familiares, quienes supuestamente deben "proteger" y brindar contención, son participes o cómplices de estos hechos, ya sea desde la acción directa o desde el silencio. Lo cual merece una reflexión sobre la familia que, lejos de ser un ámbito de armonía, seguridad y confort, en estos casos se torna un espacio de conflicto y opresión y son, justamente, los lazos de parentesco y familiares sobre cuales se monta una crueldad que vuelve posible la entrega de un niño/a y/o la mercantilización de su nacimiento. El dolor que Rosa experimenta por el robo de su hijo/a es también por su propia familia imponiéndole, de algún modo, esa "entrega forzada", avasallando su capacidad de decidir. Así la violencia y el silencio se apropiaron de la capacidad de hacer y de decir, nunca nadie le pregunto a Rosa qué quería hacer, decidieron por ella. Esto revela el carácter bifronte de los vínculos familiares y cómo funcionan las relaciones de poder al interior de la familia, un poder que no se ejerce de igual modo en todas las clases sociales. En ocasiones en los sectores populares la precariedad y la vulnerabilidad resultan el contexto de la crueldad y el descuido, como fue en los casos de Amanda y Rosa. Sin embargo, la mirada retrospectiva y la reflexión que hacen sobre su propia experiencia y el devenir de sus trayectorias vitales les permitieron construir vínculos diferentes a los heredados e incluso reclamar públicamente por sus hijos/as robados/as.

En este texto relaté la experiencia vivida de Rosa y cómo dio lugar a un reclamo de justicia inédito configurado en un determinado contexto sociohistórico. Tanto la historia Rosa como el contexto singular que hizo posible la construcción de la demanda son comprensibles recuperando la historicidad de los procesos, y ello también revela la riqueza del dialogo históricoantropológico para analizar estas cuestiones.

Por último, y teniendo presente el recorrido del artículo, quisiera subrayar que estos robos y las "entregas" (coactivas y/o voluntarias) se inscriben en tramas de relaciones sociales de desigualdad de género, y en el caso de estas mujeres son resultantes de tecnologías coactivas y de disciplinamiento corporal y moral 
(FOUCAULT, 1997; 2003) que distintos tipos de actores -parteras, médicos, intermediarios y familiares- instrumentaron para robarles a sus hijos y/o "convencerlas" de que los entregaran o que callaran ante una "muerte dudosa". En este sentido, las prácticas de circulación coactiva de niños en nuestro país (VILLALTA \& GESTEIRA, 2019) deben ser analizadas teniendo presente las historias de estas mujeres, y las formas en que históricamente ha sido conceptualizado el "abandono" -condensando siempre sentidos negativos- lo cual ha servido para culpabilizarlas y silenciarlas. Así, el hecho de que recientemente estas mujeres luego de años de silencio, de opresión y de veladas o abiertas sospechas respecto de su estado mental- se dispusieron a contar su "verdad", debe interpretarse a la luz de la sensibilización sobre el tema de los orígenes y la identidad que en Argentina ha realizado Abuelas de Plaza de Mayo, y de los efectos producidos por la ampliación de los derechos de las mujeres y las transformaciones sociales relativas a las concepciones de familia, género y sexualidad.

\section{Referencias}

ADAZKO, Ariel. Perspectivas socio-antropológicas sobre la adolescencia, la juventud y el embarazo. In: GOGNA, Mónica (coord.). Embarazo y maternidad en la adolescencia: Estereotipos, evidencias y propuestas para políticas públicas. Buenos Aires: CEDES, 2005. p. 113-162.

ALFARO-MONSALVE, Karen. Adopciones Internacionales. La lucha contra las madres solteras bajo la dictadura militar en Chile (1973-1990). In: JORNADAS NACIONALES DE HISTORIA DE LAS MUJERES. IX CONGRESO IBEROAMERICANO DE ESTUDIOS DE GÉNERO, 14., 2019, Buenos Aires. [Anales]. Argentina: Universidad de Mar del Plata, 2019. p. 1-14.

ALLEMANDI, Cecilia. Niños sirvientes y "criados": el trabajo infantil en el servicio doméstico (ciudad de Buenos Aires, fines del siglo XIX-principios del XX). Revista Cuadernos del IDES, [Buenos Aires], n. 30, p. 11-38, 2015. Disponible en: http://209.177.156.169/libreria_cm/archivos/pdf_894.pdf\#page=13. Acceso en: 12 mayo 2020.

ALLEMANDI, Cecilia. Sirvientes, criados y nodrizas: una aproximación a las condiciones de vida y de trabajo en la ciudad de Buenos Aires a partir del servicio doméstico (fines del siglo XIX-Principios del XX). 2015.Tesis doctoral (Doctorado en Historia) - Universidad de San Andrés, San Andrés, $2015 a$. Disponible en: https://repositorio.udesa.edu.ar/jspui/handle/10908/10937. Acceso en: 12 mayo 2020. 
AMANDA. Entrevista cedida a Soledad Gesteira, Tigre, Provincia de Buenos Aires, 19 de junio de 2014.

AVERSA, María Marta. El circuito de colocaciones laborales de niños y niñas asilados. Revista Angelus Novus, San Pablo, v. 8, n.10, p. 103-128, 2014. Disponible en: https://doi.org/10.11606/ran.v0i8.107902. Acceso en: 22 mayo 2020

BADINTER, Elisabeth. Existe el amor maternal: historia del amor materno: siglos XVII al XX. Barcelona: Paidós-Pomaire, 1981.

BOURDIEU, Pierre. Espíritu de familia. In: NEUFELD, María Rosa; GRIMBERG, Mabel; TISCORNIA, Sofía; WALLACE, Santiago. (comps.). Antropología Social y Política: hegemonía y poder: el mundo en movimiento. Buenos Aires: Eudeba, 1998. p. 57-64.

CARDARELLO, Andrea. The Movement of the Mothers of the Couthouse Square: "Legal Child Traffiquing", Adoption and Poverty in Brazil. The Journal of Latin American and Caribbean Anthropology, v 14, n. 1, p. 140-161, 2009.

COHEN, Stanley. Folk devils and moral panics. 3. ed. Cornwall: Routledge, 2009.

COSSE, Isabella. Ilegitimidades de origen y vulnerabilidad en la Argentina de mediados del siglo XX. Revista Nuevo Mundo Mundos Nuevos, París, v. 1, p. 1-21, 2007.

COSSE, Isabella. Pareja, sexualidad y familia en los años sesenta. Buenos Aires: Siglo Veintinuno, 2010.

DE PAZ TRUEBA, Yolanda. Cuerpos en la mira. Estrategias y discursos reglamentadores como dispositivos para naturalizar la desigualdad de género y la socialización de lo biológico. El sur bonaerense a fines del siglo XIX. Revista Escuela de Historia, Rosario, v. 1, n. 6, p.1-28. 2007

DELRÍO, Walter; RAMOS, Ana. Genocidio como categoría analítica: Memoria social y marcos alternativos. Revista Corpus, Archivos virtuales de la alteridad americana, Buenos Aires, v. 1, n. 2, p. 1-11, 2011.

DI CORLETO, Julieta. Malas madres: aborto e infanticidio en perspectiva histórica. Buenos Aires: Didot, 2018.

DI LISCIA, María. Hijos sanos y legítimos: sobre matrimonio y asistencia social en Argentina (1935-1948). Revista Histórica, Ciências, Saúde, Manguinhos, n. 9, p. 209-232, 2002.

FREIDENRAIJ, Claudia. La niñez desviada. La tutela estatal de niños pobres, huérfanos y delincuentes: Buenos Aires, 1890-1919. 2015. Tesis doctoral 
(Doctorado en Historia) - Facultad de Filosofía y Letras, Universidad de Buenos Aires, Buenos Aires, 2015.

FELITTI, Karina. Parirás sin dolor: poder médico, género y política en las nuevas formas de atención del parto en la Argentina (1960-1980). Revista História, Ciências, Saúde, Manguinhos, v. 18, n. 1, p. 113-129, 2011.

FONSECA, Claudia. Mães 'abandonantes': fragmentos de uma história silenciada. Estudos Feministas, Florianópolis, v. 20, n. 1, p. 344, 2012.

FOUCAULT, Michel. Vigilar y castigar. México, DF: Siglo XXI, 1997.

FOUCAULT, Michel. Historia de la sexualidade: la voluntad del saber. México, DF: Siglo XXI, 2003. Tomo I.

GAITÁN, Ana Cecilia. La gestión de lo inapropiado: disputas de sentidos y practicas em torno a la autonomía y la maternidad en una propuesta de inclusión social para jóvenes. Revista de Estudios de Género La Ventana, Guadalajara, n. 51, p. 215-244, 2018.

GENTILI, Agostina. Relatos judiciales, Estado y sociedad: orígenes familiares de niños adoptados en Córdoba en los sesenta. Revista Población \& Sociedad, San Miguel de Tucumán, v. 24, n. 2, p. 95-127, 2017. Disponible en:

http://www.poblacionysociedad.org.ar/archivos/24/P\&S-V24-N2- Gentili.pdf. Acceso en: 12 abril 2020.

GENTILI, Agostina. Veladuras. El servicio doméstico de niñas y jóvenes en la narrativa judicial de los años sesenta en Córdoba, Argentina. Revista Secuencia, México, DF, p. 85-118, 2018. Edición especial.

GESTEIRA, Soledad. Entre el activismo y el parentesco: lo público, lo íntimo y lo político. Las organizaciones de personas que buscan sus orígenes. 2016. Tesis doctoral (Doctorado en Antropología) - Facultad de Filosofía y Letras, Universidad de Buenos Aires, Buenos Aires, 2016.

GOGNA, Mónica. El embarazo adolescente: diagnóstico de situación y lineamientos de acción. Buenos Aires: Secretaría de Desarrollo Social, Subsecretaría de Proyectos Sociales, 1996. Mimeografado.

HUDSON, Carlos Fernando. El censo nacional de 1960 en Argentina. La distrucipn de la población como herramienta de la historia política. Revista Diacrone Studi di Storia Contemporánea, Roma, v. 4 , n. 12, p. 1-15, 2012. MEAD, Margaret. Adolescencia, sexo y cultura en Samoa. Barcelona: Planeta Agostini, 1993. 
MANZANO, Valeria. Ella se va de casa: en la era de la juventud en Argentina: cultura, política y sexualidad desde Perón hasta Videla. Buenos Aires: Fondo de Cultura Económica. 2017. p. 115-154.

MERRY, Sally Engle. Derechos Humanos y violencia de género: el derecho internacional en el mundo de la justicia local. Bogotá: Siglo del Hombre editores, 2010.

MORGADE, Graciela. Políticas de educación sexual integral - Saberes, prácticas y cuerpos en tensión. Revista Retratos da Scola, Brasilia, v. 9, n. 16, p. 63-71, jan./jun. 2015.

NARI, Marcela. La educación de la mujer (o acerca de cómo cocinar y cambiar los pañales a su bebé de manera científica). Revista del Area Interdisciplinaria de Estudios de la Mujer, Buenos Aires: Universidad de Buenos Aire, Facultad de Filosofía y Letras, n.1, p. 31-45, 1995.

NARI, Marcela. Las políticas de la maternidad y maternalismo político, Buenos Aires, 1890-1940. Buenos Aires: Biblos. 2004.

PALACIO LIS, Irene. Madres ignorantes: madres culpables: adoctrinamiento y divulgación materno-infantil en la primera mitad del siglo XX. Valencia: Universitat de Valencia, 2003.

PALOMAR VEREA, Cristina. Malas madres: la construcción social de la maternidad. Debate feminista, México, DF, año 15, v. 30, p.12-25, oct. 2004.

PITA, María Victoria. La construcción de la maternidad como lugar político en las demandas de justicia: familiares de víctimas del terrorismo de Estado y de la violencia institucional en Argentina. Arena, Revista de historia de las mujeres, Granada, v 8, n. 1, p. 127-154, 2001.

ROSA. Entrevista cedida a Soledad Gesteira, González Catán, Provincia de Buenos Aires, 5 de noviembre 2018.

REGUEIRO, Sabina. Apropiación de niños, familias y justicia, Argentina (1976-2012). Rosario: Prohistoria Ediciones, 2013.

SALVO AGOGLIA, Irene; HERRERA, Florencia. "I Assumed He Didn't Exist": The Birth Father as the Invisible Member of the Adoption Kinship Network. Revista Journal of Family Issues, v 42, n.5, p. 984-1006, 2020.

SALVO AGOGLIA, Irene; SAN ROMAN, Beatriz. [Re]visitando a la madre [des]naturalizada: búsquedas y encuentros entre personas adoptadas en Chile y sus madres de origen”. Revista de Estudios Sociales, Bogotá, n. 68, p.75-87, 2019 
SCHNEIDER, David. A critique of the study of kinship. Ann Arbor: University of Michigan Press, 1984.

SIMMEL, George. Filosofía del dinero. Madrid: Instituto de Estudios políticos, 1976.

TARDUCCI, Mónica. Maternidades y adopción: introducción desde la antropología de género. In: TARDUCCI, Mónica (org.). Maternidades en el siglo XXI. Buenos Aires: Espacio Editorial, 2008. p.15-27.

TARZIBACHI, Eugenia. Cosa de Mujeres: menstruación, género y poder. Buenos Aires: Sudamericana, 2017.

TUBERT, Silvia. Figuras de la madre. Valencia: Ediciones Cátedra: Universitat de Valencia: Instituto de la mujer, 1996.

TISCORNIA, Sofía. Activismo de los derechos humanos y burocracias estatales: el caso de Walter Bulacio. Buenos Aires: Del Puerto, 2008.

VIANNA, Adriana; FARIAS, Juliana. A guerra das mães: dor e política em situações de violência institucional. Revista Cadernos Pagú, São Paulo, v 37, p.79-116, jul./dez. 2011.

VILLALTA, Carla. Entregas y secuestros: el rol del Estado en la apropiación de niños. Buenos Aires: Del Puerto, 2012.

VILLALTA, Carla; GESTEIRA, Soledad. Prácticas de circulación coactiva de niños y niñas en la Argentina. Tramas institucionales, jerarquías sociales y derechos. Revista Runa. Instituto de Ciencias Antropológicas. Facultad de Filosofía y Letras. Universidad de Buenos Aires, Buenos Aires, v. 40, n. 2, p. 149-167, 2019.

ZELIZER, Viviana. Pricing the priceless child: the changing social value of children. Princeton: Princeton University Press, 1992.

Universidade do Estado de Santa Catarina - UDESC

Programa de Pós-Graduação em História - PPGH

Revista Tempo e Argumento Volume 13 - Número 33 - Ano 2021 tempoeargumento@gmail.com 